Батьковец̧ь H. O., natabatkovets72@gmail.com,ORCID ID:0000-0003-3003-5039,

к.е.н., доц., дочент кафедри економіки та маркетингу ВСП Навчально-науковий Інститут підприємництва та перспективних технологій Національного університету “Львівська політехніка”, м. Львів

Батьковеиь Г. А., ORCID ID: 0000-0001-9268-7580,

к.е.н., дои., доцент кафедри менеджменту, Хмельницьький кооперативний торговельно-економічний інститут, м. Хиельницький

\title{
ЕМОЦІЙНИЙ ІНТЕЛЕКТ ЯК СКЛАДОВА РОЗВИТКУ ПЕРСОНАЛУ ТОРГОВЕЛЬНИХ ПІДПРИЕМСТВ
}

\begin{abstract}
Анотація. У статті розглянуто вплив емоційного інтелекту на ефективність виконання професійних функцій, наведено взаємозв'язок між вмінням працівника керувати емоційним інтелектом та результатом його праці. Визначено суб'єктивні та об'єктивні показники, які впливають на зародження різних типів емоцій. Наведено класифікацію зовнішніх та внутрішніх структуроутворюючих чинників емочійного інтелекту працівника. Розглянуто суб' єктивні та об 'єктивні складові емочійного стану індивідуума, які формують реакцію на стрес-фактори $i$ рівень зрозумілості подразника. Визначено основні показники сталої поведінки працівників підприємства та ї̈ впливу на функціональну ефективність виконуваних обов'язків. Доведено, щзо вміння працівника керувати емоційним інтелектом впливає на результативність його праці та можливість кар'єрного росту чи ротації в організації. Наведено загальнонаціональний показник Украӥни у всесвітньому рейтингу щуастя як базовий при формуванні емоційного фону населення. Доведено, щчо відсутність у моделі розвитку персоналу заходів, які дозволяють управляти емоційним станом працівника, може призвести до ряду негативних наслідків, які наведені у статті. Визначено, щчо професійний розвиток персоналу потрібно планувати з врахуванням профільних та особистісних компетенцій. Сформовано модель професійного розвитку персоналу з врахуванням суб'єктивних (локально орієнтованих) компетениій. Окреслено взаємозв'язок між ключовими факторами успіху та професіоналізмом кадрового складу через призму емоційної грамотності. Доведено, щуо емоційний стан працівників підприємств невиробничої сфери визначає стан купівельної поведінки та готовність споживача до товарообміну.
\end{abstract}

Ключові слова: емоційний інтелект, компетенції, розвиток персоналу, психологічний клімат, емоційна грамотність.

Batkovets N. O., natabatkovets72@gmail.com,ORCID ID:0000-0003-3003-5039, Ph.D., Associate Professor, Associate Professor of the Department of Economics and Marketing, Educational-Scientific Institute of Entrepreneurship and Advanced Technologies of the "Lviv Polytechnic" National University, Lviv

Batkovets G. A., ORCID ID: 0000-0001-9268-7580,

Ph.D., Associate Professor, Associate Professor of the Department of Management, Khmelnytsky Cooperative Institute of Trade and Economics, Khmelnytsky

\section{EMOTIONAL INTELLIGENCE AS A COMPONENT OF STAFF DEVELOPMENT OF TRADE ENTERPRISES}

\begin{abstract}
The article considers the influence of emotional intelligence on the effectiveness of professional functions performance as well as the relationship between the ability of the employee to manage emotional intelligence and the results of his work. Subjective and objective indicators that affect the emergence of different types of emotions are identified. The classification of external and internal structure-forming factors of emotional intelligence of the employee is given. The subjective and objective components of the emotional state of the individual, which form the reaction to stress factors and the level of comprehension of the stimulus, are considered. The main indicators of sustainable behavior of employees and its impact on the functional efficiency of the performed duties are identified. It has been proven that an employee's ability to manage emotional intelligence affects the effectiveness of his work and the possibility of
\end{abstract}




\title{
Herald of Lviv University of Trade and Economics. Economic Sciences. № 62, 2021
}

career growth or rotation in the organization. The national indicator of Ukraine in the world rating of happiness as a base in the development of the emotional background of the population is given. It is proved that the lack of measures in the staff development model that allow you to manage the emotional state of the employee can lead to a number of negative consequences, which are presented in the article. It is determined that the professional development of staff should be planned taking into account the profile and personal competencies. The model of professional development of the personnel taking into account subjective (locally oriented) competences is developed. The relationship between key success factors and staff professionalism through the prism of emotional literacy is outlined. It is proved that the emotional state of employees of non-productive enterprises determines the state of purchasing behavior and consumer readiness for trade.

Key words: emotional intelligence, competencies, staff development, psychological climate, emotional literacy.

\author{
JEL Classification: M12 \\ DOI: https://doi.org/10.36477/2522-1205-2021-62-08
}

Постановка проблеми. Сучасний ринок товарів і послуг - динамічний механізм взаємодії суб'єктів та об'єктів. Сталі та звичні чинники розвитку ринку, його модифікації втрачають вагу, натомість появляються нові складові, які через свої характерні ознаки можуть бути домінуючими. Збалансований розвиток певного сектора ринку потребує усвідомлення низки структуроутворюючих складових, які визначають імідж підприємства та його авторизацію в суспільстві. Безумовно, для кожного індивідуального підприємства складовими успіху можуть бути різні фактори, однак для нематеріальної сфери базові дублюються. Особливо це стосується підприємств торговельної сфери, бізнеспроцеси яких прямо пропорційно залежать від персоналу.

Аналіз останніх досліджень та публікацій. Формуючи принципові показники ефективного персоналу, досить часто не звертають увагу на психічні, психологічні та емоційні характеристики. Результати традиційних співбесід та тестових завдань часто не відповідають та спотворюють загальну характеристику працівника, тим паче, якщо через них визначають здатність до виконання тих чи інших функцій. 3 цих причин науковці почали активно займатися дослідженнями в сфері розвитку нематеріальних активів підприємства, які призвели до появи таких понять, як “організаційна психологія”, “емоційний інтелект”, “статика емоційної поведінки”. Грунтовними та цікавими доробками науковців сьогодення $є$ положення таких вчених, як: Г. П. Рекун, В. В. Меденець, П. Селовей, Н. Холл, Дж. Мейер, С. Колот та інші.

Постановка завдання. Метою статті $\epsilon$ вивчення та дослідження чинників суб'єктивного характеру та їх вплив на кадровий потенціал підприємств торговельної сфери і його розвиток.

Виклад основного матеріалу дослідження. Інноваційні технології, імплементація прикладів зарубіжних країн зумовлюють появу нових форм та методів купівлі-продажу товарів та послуг, які вимагають від керівників торговельних підприємств не просто формування штатного розпису, але застосування моніторингу персоналу на здатність виконувати певні функції. Електронні системи, штучний інтелект, інформаційні технології уможливлюють оптимізацію механічної праці, однак процес обміну товарів на фінансовий еквівалент здійснює в більшості випадків персонал.

Питання розвитку персоналу досить пропрацьовано в науковій сфері, сформовані моделі розвитку персоналу, визначені критерії оцінювання якості персоналу, визначені джерела набору та підбору персоналу, приділено багато уваги адаптації персоналу до умов праці. Керівники підприємств часто нівелюють такі чинники, як саморозвиток персоналу, навички критичного мислення, управління емоційним інтелектом, приділяючи увагу професійним компетенціям та попередньо досягненим результатам. Звісно, ключові фактори успіху та професіоналізму кадрового складу потрібно визначати через чіткі критерії, які $€$ вимірюваними i можливими до порівняння. Однак ті фактори, які є видимими, не завжди дають повну та грунтовну оцінку для формування моделі розвитку персоналу. Особливо це стосується підприємств нематеріальної сфери, оскільки від професіоналізму, інтелекту та емоційного стану виконавчих працівників залежить ефективність роботи 3 клієнтською базою. Адже в сучасних умовах сегментація ринку - це не лише прописаний класифікатор потенційних споживачів, але і вміння працювати 3 кожним індивідуально, розуміючи психотипізацію та передбачаючи стан купівельної поведінки. Цей взаємозв'язок $\epsilon$ очевидним i, як наслідок, впливає на загальні економічні показники ефективності функціонування торговельного підприємства.

Одним із багатовекторних чинників у цьому ланцюзі $\epsilon$ емоційний інтелект працівників торговельного підприємства та вміння ним керувати. Якщо на перший погляд цей чинник може здатися малозначущим, то у виробничих ситуаціях (а для працівників торговельного підприємства це комунікації з реалізації бізнес-процесу) товарообмін може призвести до неминучого спаду товарообігу.

Класично ми розуміємо, що психологічний клімат у колективі впливає на продуктивність праці, але, яким чином він формується, часто не задумуємося. Безперечно, соціум визначає та корегує основні моделі поведінки. Суб'єктивні та об'єктивні складові емоційного стану індивідуума формують реакцію на стрес-фактори і рівень 
зрозумілості подразника. Вони можуть бути як зовнішніми, так і внутрішніми. Доведено, що вміння працівника керувати емоційним інтелектом впливає на результативність його праці та можливість кар'єрного росту чи ротації в організації.

Якщо розглядати емоційний інтелект, то базовим ключовим словом є “емоції”. Як зауважує Карпенко Є. В., “емоції постають реакцією на сторонні стимули, самі потребують контролю, і в разі його відсутності становлять загрозу" [4]. Власне, для випередження настання стану емоційного збою необхідно імплементувати в систему управління розвитком персоналу підприємства так звані принципи управління емоційним інтелектом.

До прикладу, в японській моделі менеджменту новою парадигмою управління розвитком людських ресурсів став саме емоційний інтелект. Науковці багатьох галузей долучаються до дослідження емоційного інтелекту як певної властивості індивідуума. Однак, на жаль, єдиних згрупованих правил наразі немає.

На нашу думку, емоційний інтелект - це свідоме управління емоціями, яке можливо опанувати через систему знань та сформувати модель емоційної компетентності. Необхідно зважати на те, що виникнення тих чи інших емоцій у працівників може бути викликано як суб'єктивними (внутрішніми), так і зовнішніми факторами, які не залежать від способу життя людини, іiі внутрішніх стимулів та поглядів. До основних таких показників можна віднести наступні:

- Політична система, задоволення від статусу громадянина тої чи іншої країни;

- Екологічна система, якість життя.

- Рівень громадської свідомості.

- Соціальна підтримка в країні.

- Захист від настання кризових ситуацій.

- Безпека життя, медицини, освіти.

- Реалізація професійних амбіцій у трудовому житті.

- Задоволеність статусом, посадою, заробітною платою.

- Психологічний клімат в організації, на підприємстві.
- Благополуччя, можливість забезпечення потреб.

- Мотивація до самовдосконалення та самореалізації, інші.

Емоційний стан населення країни почали досліджувати з 2012 року через визначення так званого всесвітнього рейтингу щастя World Happiness Report, який щороку складають у межах ініціативи $\mathrm{OOH}$, проводячи порівняльні дослідження між 156 країнами, а також індексу соціального розвитку та людського розвитку. Для його визначення використовують систему 333 показників, які, на думку експертів, впливають на емоційний стан людини. Серед основних показників: ВВП на душу населення, рівень соціальної підтримки, тривалість життя, свобода вибору, рівень корупції та наявність негативних очікувань від майбутнього [10]. Щодо населення України, то цей показник досить нестабільний (рис. 1).

Як видно з рисунку, загальні фактори досить суттєво впливають на емоційний стан людини. Щодо можливості вимірювання рівня емоційного інтелекту для працівників, використовується стандартизований тест Майєра-Саловея-Карузо, розроблений у 2002 році.

Індекс соціального прогресу (The Social Progress Index) - це інтегрований показник дослідного проекту The Social Progress Imperative, який оцінюється за 50 показниками, які групуються. За результатами дослідження, Україна посіла 80 місце 3 143 позицій у 2019 році з рейтингом 66,97. Цікаво, що всі показники згруповані за структурою: якість забезпечення основних потреб людини; рівень благополуччя (освіта, здоров'я, медицина, екологічна збалансованість); можливості розвитку людини [10].

Ще одним цікавим загальним показником емоційного стану населення країни є оцінка людського розвитку, індекс якого визначає сукупний показник рівня розвитку людини. Україна за цим показником посіла 88 місце з 189 у 2019 році та отримала індекс $0,75[10]$.

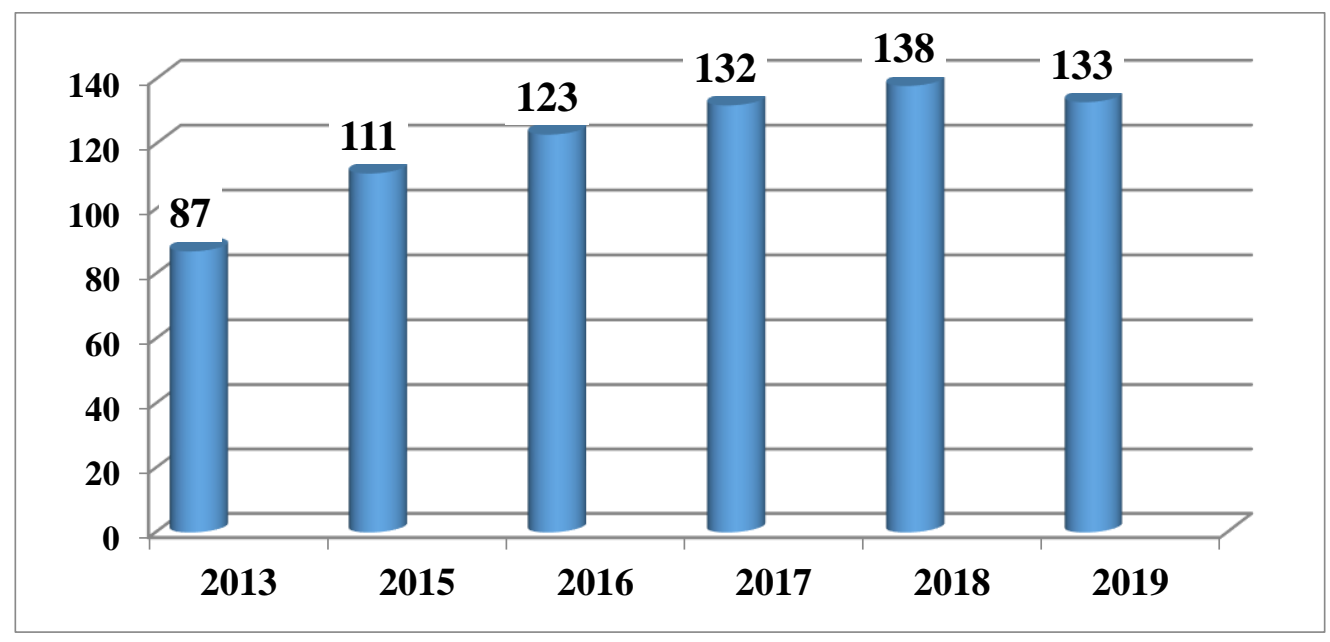

Рис. 1. Рейтинг України у всесвітньому рейтингу щастя [10] 


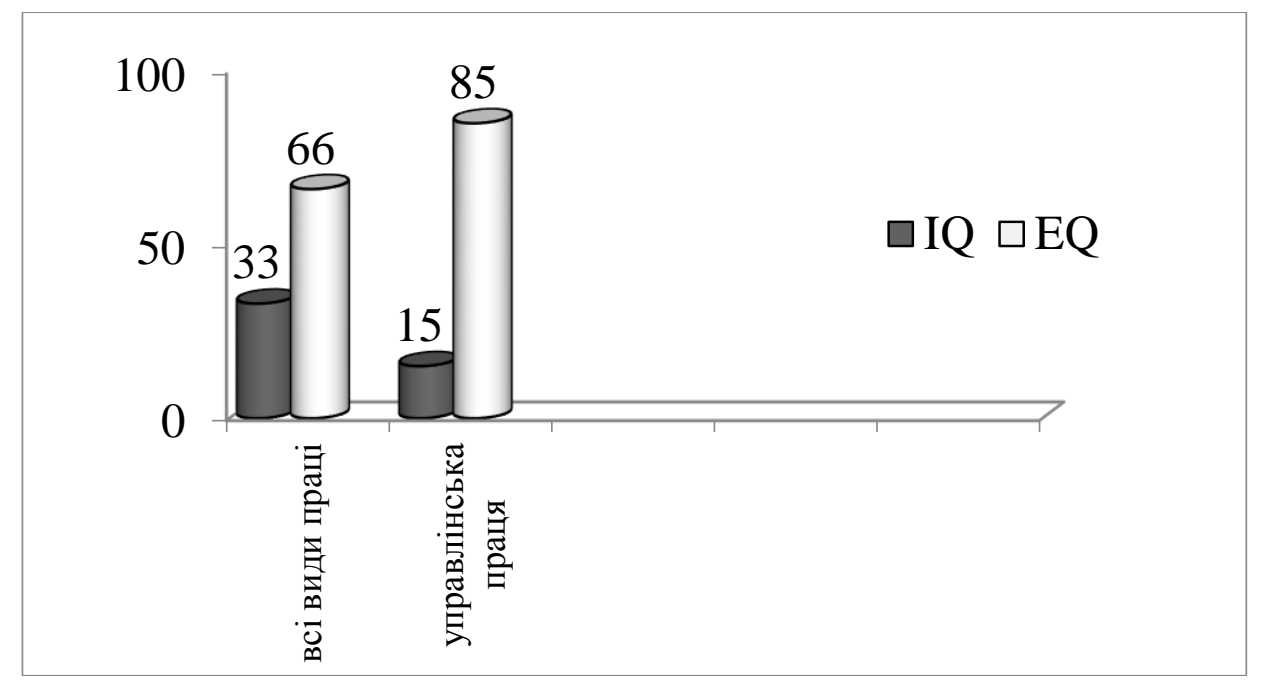

Рис. 2. Вплив IQ та EQ на результати праці [6]

\section{Професійний розвиток персоналу}

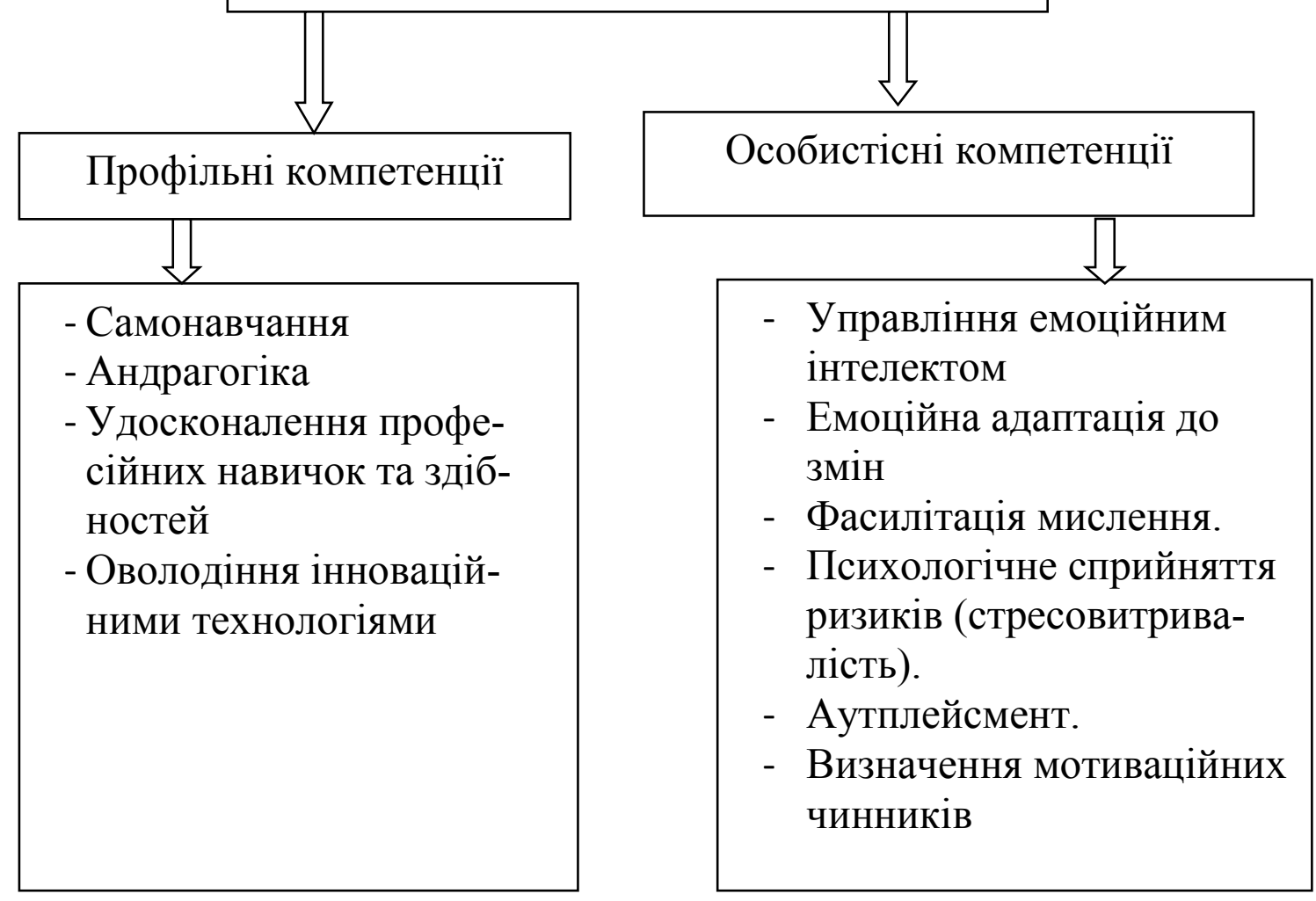

Рис. 3. Складові професійного розвитку персоналу

Визначаючи складові моделі розвитку персоналу, адміністрація підприємства закладає фундаментальні положення щодо професійного удосконалення та формування конкурентних компетентнісних характеристик. Відсутність у цій моделі заходів (інструментів), які дозволяють управляти емоційним станом працівника, може призвести до негативних наслідків, а саме:

- Настання однієї зі стадій професійного вигорання.
- Нестабільний психологічний клімат у колективі.

- Посилення впливу стрес-факторів на емоційну стабільність працівника, а відтак зменшення продуктивності праці.

- Наявність статичних конфліктів, які деформують уявлення про задоволення роботою.

- Відсутність у працівників самоактуалізації, тобто унеможливлення реалізувати потенціал. 
- $\quad$ Зниження рівня емпатії, відсутність потреби розуміти емоції та стани інших працівників, в тому числі і потенційних споживачів.

- Загроза підвищення показника плинності кадрів, а це сприятиме зниженню якості виконання професійних функцій та втраті ядра колективу.

- З Зниження мотиваційної поведінки, байдужість до результатів праці.

- Відсутність ознак асертивності, що призводить до нівелювання рамок конструктивного вирішення проблеми.

Виконання професійно-орієнтованих функцій у кожного працівника поєднується 3 переліком емоцій, якими необхідно управляти грамотно.

Емоційна грамотність працівників дозволить конструктивно поєднувати емоції та ефективне виконання функцій. Тому модель розвитку персоналу, на нашу думку, доцільно формувати, включаючи оцінювання емоційного інтелекту працівників. Спираючись на дослідження Д. Гоулмана [1], можна стверджувати, що рівень IQ працівників прямо пропорційно впливає на рівень EQ (рис. 2).

Отже, професійний розвиток персоналу потрібно планувати з врахуванням профільних та особистісних компетенцій (рис. 3).

Використовуючи наведені складові, можливо забезпечити баланс між робочою атмосферою та результатами праці. За дослідженнями С. Колота, на кожен відсоток поліпшення робочої атмосфери припадає 2\% зростання доходу [5].

Висновки i перспективи подальших досліджень у даному напрямі. Отже, перелік негативних наслідків доводить, що для ефективної моделі розвитку персоналу недостатньо володіти професійними компетенціями чи здатністю до удосконалення практичних навичок, необхідно застосовувати синергічні методи для професійного зростання чи побудови своєї кар'єри, які грунтуються на базових положеннях сутності та управління емоційним інтелектом.

Саме підвищення емоційного інтелекту та розвиток емоційної компетентності сприяє адекватному розумінню особистістю витоків своїх емоцій та емоцій інших людей, допомагає здійснювати на цій основі самоконтроль, зберігати психологічну рівновагу та впевнено досягати бажаного результату.

Дослідження розглянутої в статті проблематики управління емоційним інтелектом буде актуальним i в перспективі, оскільки формування професійних компетенцій не залежатиме виключно від технічних інновацій, але включатиме моделі поведінки та раціонального визначення комунікативних зв'язків, які передбачають від індивідуума не тільки володіння професійною майстерністю, але i стабільну поведінку, що керується принципами емоційного інтелекту.

\section{ЛIТЕРАТУРА}

1. Дэниел Гоулмен. Эмоциональное лидерство. Искусство управления людьми на основе эмоцио- нального интеллекта / Дэниел Гоулмен, Ричард Бояцис, Энни Макки. - М. : Альпина Бизнес Букс, 2007. - 304 c.

2. Дерев'янко С. Актуалізація емоційного інтелекту в емоціогенних умовах / С. Дерев'янко // Соціальна психологія. - Київ, 2008. - 1 (27). C. 96-104.

3. Дубовик С. Г. Розвиток емоційного інтелекту сучасних менеджерів як основа їх успішної діяльності / Дубовик С. Г., Драбчук Т. І. // Вісник Сумського національного аграрного університету. Серія “Економіка і менеджмент". - 2014. - Вип. 5. C. 8-14.

4. Карпенко Є. В. Сучасні вектори дослідження емоційного інтелекту особистості / С. В. Карпенко // Психологія і особистість. - 2019. - № 1(15). C. 60-72.

5. Колот С. О. Поліфункціональна спрямованість емоційного менеджменту в системі організаційного управління / С. О. Колот // Наука i освіта. - 2007. - № 8-9. - С. 63-67.

6. Корман М. М. Емоційний інтелект персоналу як основа ефективного розвитку організації / М. М. Корман // Наукові праці Кіровоградського національного технічного університету. Економічні науки, 2013. - Вип. 24. - С. 88-93.

7. Козлова В. Технологія EQ-BOOSt. Як використовувати емоційний інтелект у бізнесі та житті / В. Козлова; перекл. С. Осока. - Львів : Видавництво Старого Лева, 2019. - 176 с.

8. Корман М. М. Розвиток емоційного інтелекту та емоційної компетентності як передумова запобігання професійного вигорання / М. М. Корман // Вісник Національного університету оборони України - 4 (29)/2012. С. 175-178.

9. Меденець В. В. Емоційне лідерство в системі управління персоналом / В. В. Меденець // Економіка і суспільство. - 2017. - Вип. 13 -С. 691-696 [Електронний ресурс]. - Режим доступу: http://www.economyandsociety.in.ua/journal/13_ukr/1 17.pdf.

10. Организация экономического сотрудничества и развития PIAАC. / Центр гуманитарных технологий. - 08.10.2013 [Електронний ресурс]. - Режим доступу: https:/gtmarket.ru/news/ 2013/10/08/ 6299.

11. https://gtmarket.ru/news/2013/10/08/6299.

12. https://maximum.fm/novini_t2.

\section{REFERENCES}

1. Denyel Houlmen, Rychard Boiatsys and Enny Makky (2007), Emotsyonal'noe lyderstvo. Yskusstvo upravlenyia liud'my na osnove emotsyonal'noho yntellekta, Al'pyna Byznes Buks, M., 304 s.

2. Derev'ianko S. (2008), Aktualizatsiia emotsijnoho intelektu v emotsiohennykh umovakh, Sotsial'na psykholohiia, Kyiv, 1 (27), s. 96-104.

3. Dubovyk, S. H. and Drabchuk, T. I. (2014), Rozvytok emotsijnoho intelektu suchasnykh menedzheriv iak osnova ikh uspishnoi diial'nosti, Visnyk Sums'koho natsional'noho ahrarnoho univer- 
sytetu. Seriia "Ekonomika i menedzhment", vyp. 5, s. 8-14.

4. Karpenko, Ye. V. (2019), Suchasni vektory doslidzhennia emotsijnoho intelektu osobystosti, Psykholohiia i osobystist', № 1(15), s. 60-72.

5. Kolot, S. O. (2007), Polifunktsional'na spriamovanist' emotsijnoho menedzhmentu v systemi orhanizatsijnoho upravlinnia, Nauka i osvita, № 8-9, s. 63-67.

6. Korman, M. M. (2013), Emotsijnyj intelekt personalu iak osnova efektyvnoho rozvytku orhanizatsii, Naukovi pratsi Kirovohrads'koho natsional'noho tekhnichnoho universytetu. Ekonomichni nauky, vyp. 24, s. 88-93.

7. Kozlova V. (2019), Tekhnolohiia EQ-BOOSt. Yak vykorystovuvaty emotsijnyj intelekt u biznesi ta zhytti ; perekl. S. Osoka, Vydavnytstvo Staroho Leva, L'viv, $176 \mathrm{~s}$.

8. Korman, M. M. (2012), Rozvytok emotsijnoho intelektu ta emotsijnoi kompetentnosti iak peredumova zapobihannia profesijnoho vyhorannia, Visnyk Natsional'noho universytetu oborony Ukrainy, 4 (29), s. 175-178.

9. Medenets', V. V. (2017), Emotsijne liderstvo v systemi upravlinnia personalom, Ekonomika $i$ suspil'stvo, vyp. 13, s. 691-696, available at: http://www.economyandsociety.in.ua/journal/13_ukr/1 17.pdf.

10. Orhanyzatsyia ekonomycheskoho sotrudnychestva y razvytyia PIAAC ; Tsentr humanytarnykh tekhnolohyj. - 08.10.2013, available at: https://gtmarket.ru/news/2013/10/08/6299.

11. https://gtmarket.ru/news/2013/10/08/6299.

12. https://maximum.fm/novini_t2.

Стаття надійшла до редакиіï 07 грудня $2020 \mathrm{p}$. 